\title{
Barbara U. Meyer Jesus the Jew in Christian Memory: Theological and Philosophical Exploration
}

\author{
(Cambridge: Cambridge University Press, 2020), xi + 212 pp.
}

\author{
EDWARD KESSLER \\ edk21@cam.ac.uk \\ Woolf Institute, Cambridge, England
}

This book is a profound and engaging reflection on the theological significance of the Jewishness of Jesus. The author acknowledges widespread recognition of the fact that Jesus was born, lived, and died a Jew, yet, she argues, its significance, particularly for Christology, has yet to be digested by Christian theologians.

The focus, as the title makes clear, is on the relevance of memory, which means, for example, that Jesus's Jewishness needs to be reflected in Christian dogma (from the earliest times to present day). The book begins with a study of inter-religious understandings of memory, starting with Jewish approaches, which need to be taken especially seriously by Christian theologians. Memory is not just historical but connects with the present. For Meyer, Christian memory cannot be formulated without Jewish memory, as Christianity shares so much with Judaism.

In an early section exploring Jesus in his Jewish context, she considers what type of Jew he was, examining late $19^{\text {th }}$ and early $20^{\text {th }}$ Jewish scholarship on Jesus, such as the views of Harry Austryn Wolfson (as analyzed by Zev Harvey), although she might also have included the contribution of Claude Montefiore, an often unappreciated Jewish scholar of this period. One of the strengths of Meyer's approach is that she explains and then builds on a wide array theological writings, not only Protestant and Roman Catholic but Jewish as well. As Professor of Religious Studies in Tel-Aviv University, she is immersed in the study of first-century Judaism as well as contemporary Jewish thought, making this volume both insightful and sensitive to Christian-Jewish reconciliation. She explains that contemporary Jews, like Christians, are increasingly comfortable recognizing the Jewishness of Jesus, but Christians also need to believe in the presence of Christ and the ongoing covenant between God and the Jewish people. This means that Jesus's being Jewish is not a Jewish but a Christian statement of faith. Thus, although the contemporary Jewish witness to Jesus the Jew has Christological significance, there must be a clear division between Jews recognizing Jesus as Jewish and Christian interpretations of the significance of his Jewishness. 
Christologically, Meyer argues, Jesus' Jewishness opens up new horizons for (non-Jewish) Christians as well as for a deepening of Jewish-Christian relations. She builds on Karl Barth's statement that Jesus was not coincidently but necessarily a Jew and develops an inter-religious hermeneutic of vulnerability. She argues that the answer to Dieter Bonhoeffer's question, "Who is Jesus Christ for us today?" cannot be provided by Christians alone, which is why interreligious dialogue (including with Muslims) is vital.

Not only is Jesus's Jewishness key to Christian self-understanding but Jesus' affinity with the Pharisees (including his halakhic observance) needs to be taken seriously by theologians. What does it mean for Christians that Jesus was a halakhic Jew? Placing Jesus in opposition to Torah is a common trait of Christian anti-Judaism but is also erroneous and damaging to Christianity. Meyer writes, "Jesus the Jew observed the commandments of the Torah, and Jesus Christ fulfilled the Torah, without abrogating it" (54). Therefore, Christian memory needs to witness the Torah-observant Jesus, a "halakhic Jew" who was an "active, even passionate, participant in halakhic discussion" (65).

Consequently, in a section on the Telos of Torah (and on the writings of Paul in general), Meyer points out that there is no Christ without Torah, which means it makes no sense to oppose Torah and Christ in systematic theology: "Once Jesus is inseparably connected to Torah, historical as well as Christological statements contrasting him to 'law' become less plausible" (182).

Reminding Christians that Jesus lived as a halakhic Jew is also a bulwark against heresy. In a chapter on otherness, a central category to her exploration of Christology, she engages in a fascinating (but fictional) dialogue between Tillich and Kayko Driedger Hesslein, a contemporary Lutheran theologian. The Jewish Jesus is the other and ignoring his otherness leads to Docetism or Arianism, while ignoring his Jewishness leads to the heresy of Marcionism.

Jesus' Jewishness as 'otherness' also prompts her to engage with Palestinian theology and Black theology. For example, she quotes James Cone that "Jesus is black because he was Jewish" (69). This concept of otherness means Jewishness becomes the signature of taking sides with the disadvantaged. In this example, his blackness and Jewishness constitute elements of Christology.

One of the most potent chapters deals with the suffering of Jesus the Jew, which, she argues, helps Christians remember the suffering of the other. The Holocaust also challenges Christian theologians to re-think the concept of redemptive suffering through the suffering of Christ: "The memory of the Shoah shakes Christians up" (135). Identifying a Jesus who suffers as a Jew is especially challenging for Christians, epitomized by her reflection on Levinas' concept of Useless Suffering, and she is one of the few Christian scholars to consider its implications for Christian claims (alongside Alice Eckardt).

In sum, "the memory of Jesus the Jew keeps Christianity vulnerable" (187) and, by implication I would suggest, helps Christians walk along his path and fulfil his teachings. 